\title{
Neospora caninum DNA distribution in tissues of gerbils as experimental models of chronic neosporosis
}

[Distribuição do DNA de Neospora caninum em tecidos de gerbilos como modelos experimentais de neosporose crônica]

G. Toscan ${ }^{1}$, A.S. Cezar ${ }^{1,2}$, P. Bräunig ${ }^{1 *}$, G.R. Pereira ${ }^{1}$, A.C. Vargas $^{1}$, L.A. Sangioni ${ }^{1}$, P.B.D. Gonçalves ${ }^{1,3}$, F.S.F. Vogel $^{1}$

${ }^{1}$ Universidade Federal de Santa Maria - Santa Maria, RS

${ }^{2}$ Universidade Regional do Noroeste do Estado do Rio Grande do Sul - Ijuí, RS ${ }^{3}$ Universidade Federal do Pampa - Bagé - RS

\begin{abstract}
Neospora caninum is the main etiologic agent of neosporosis in domestic animals and its pathogenesis comprises two characteristic phases: acute and chronic. Rodents are used as experimental models to mimic acute and chronic bovine neosporosis. In this study, we inoculated a total of 27 female gerbils, with different doses of $N$. caninum tachyzoites aiming to induce chronic disease. DNA was extracted from different organs of each animal after spontaneous death or euthanasia. Encephalic tissues were submitted to a highly sensitive real time PCR aiming to detect chronically infected animals. All the other samples were submitted to standard PCR. A total of 11 gerbils died due to acute neosporosis, as confirmed by $N$. caninum DNA detection in organs. $5 \times 10^{3}$ tachyzoites $/ \mathrm{mL}$ of $N$. caninum was the dosage of antigen that can induce chronic infection in gerbils. In the encephalon sections of some animals that showed clinical signs of persistent infection, we found $70 \%$ positive for the anterior encephalon section, suggesting this area as preferential for cyst formation. Therefore, we determined the doses of tachyzoites that cause acute or chronic infection and detection of positive tissues, preferably, systemic organs during acute and encephalon in chronic phases.
\end{abstract}

Keywords: Meriones unguiculatus, chronic infection, neosporosis, encephalon

\section{RESUMO}

Neospora caninum é o principal agente etiológico da neosporose em animais domésticos, e sua patogênese compreende duas fases características: aguda e crônica. Roedores são usados como modelos experimentais para simular neosporose bovina aguda e crônica. Neste estudo, foi inoculado um total de 27 gerbilos, fêmeas, com diferentes doses de taquizoítos de N. caninum, visando induzir doença crônica. O DNA foi extraído de diferentes órgãos de cada animal após a morte espontânea ou a eutanásia. Os tecidos encefálicos foram submetidos à PCR em tempo real de alta sensibilidade para detecção de animais com infecção crônica. Todas as outras amostras foram submetidas à PCR padrão. Um total de 11 gerbilos morreu devido à neosporose aguda, como confirmado pela detecção de DNA de N. caninum nos órgãos. A dosagem de antígeno que pode induzir infecção crônica foi de $5 \times 10^{3}$ taquizoítos $/ \mathrm{mL}$ de $\mathrm{N}$. caninum. Em seções do encéfalo de alguns animais, que apresentaram sinais clínicos de infecção persistente, encontraram-se $70 \%$ de positividade para a seção do encéfalo anterior, sugerindo essa área como preferencial para a formação de cisto. Assim, foram determinadas, em gerbilos, as dosagens de taquizoítos capazes de induzir infecção crônica ou aguda, bem como foram detectados tecidos positivos, preferencialmente, em órgãos sistêmicos, na fase aguda, e no encéfalo, na crônica.

Palavras-chave: Meriones unguiculatus, infecção crônica, neosporose, encéfalo

Recebido em 9 de agosto de 2019

Aceito em 6 de janeiro de 2020

*Autor para correspondência (corresponding author)

E-mail: pbraunig@gmail.com 


\section{INTRODUCTION}

$N$. caninum infection is a major cause of abortion in cattle and can cause myositis, encephalitis and several reproductive disorders in many species of mammals (Dubey and Schares, 2011). Canids are the definitive hosts and become infected by ingestion of infected tissues from intermediate hosts which comprise a wide range of animals (Dubey and Lindsay, 1996).

Neosporosis may be evaluated in two phases: acute and chronic disease. After infection, the parasite may be found in a form of rapid multiplication and cell invasion named tachyzoite and tends to evade immune response of the host forming tissue cysts containing bradyzoites in the chronic phase. Therefore, tachyzoites are the predominant form in acute neosporosis and tissue cysts containing bradyzoites characterize the chronic disease (Dubey and Lindsay, 1996). The clinical consequences of these two phases differ significantly (Aguado-Martínez et al., 2009) and this is fundamental to the determination of replication sites of $N$. caninum and its location in animal tissue. Therefore, the determination of the regions that are most likely to be the location of the cysts with bradyzoites in bovine tissues is of great importance for the understanding of the pathogenesis and diagnosis of neosporosis. However, the use of cattle in studies on pathogenesis is expensive and time consuming (Innes et al., 2000).

Different types of laboratory animals have been used as experimental models, in addition to providing an economic and convenient system to study neosporosis and consequently to test vaccines against neosporosis (Ellis et al., 2008). Gerbils (Meriones unguiculatus) are laboratory animals that are often used as an experimental model to mimic the infection of cattle, because gerbils are considered to be highly susceptible to the replication of the parasite without prior immunosuppression (Gondim et al., 2001; Costa et al., 2018).

Therefore, this study used gerbils as experimental model, aiming to determine the tachyzoites inoculation dosage and presence of $N$. caninum DNA in different tissues from acute and chronic infected animals, enabling the use of conventional PCR and real time PCR (qPCR) techniques for diagnosis and to establish which sites are preferable for cysts localization of the parasite in these animals, especially in the central nervous system (CNS).

\section{MATERIAL AND METHODS}

Twenty-seven female gerbils (M. unguiculatus) aged six weeks were divided in three groups and inoculated by the intraperitoneal route with different doses of $N$. caninum tachyzoites: $5 \times 10^{4}$

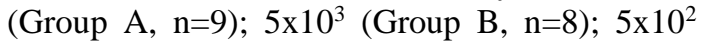
(Group C, n=10) tachyzoites/mL. Animals were individually numbered as described in Tables 1 and 2. The inoculums doses were established with basis on the previous characterization of acute neosporosis in female gerbils (Ramamoorthy et al., 2005). The animals were housed in controlled conditions of temperature and humidity with food and fresh water ad libitum during the entire experimental period and the trial was approved by the Internal Ethics Committee on Animal experimentation of Universidade Federal of Santa Maria CIETEAUFSM, Number: 92/2010.

Tachyzoites of the Nc-1 strain of $N$. caninum were cultured in Vero cells with RPMI at $37^{\circ} \mathrm{C}$ and $5 \% \quad \mathrm{CO}_{2}$ for multiplication. They were recovered from the cell cultures, counted in a Neubauer chamber and prepared for inoculation by dilution in RPMI medium at the desired doses for each experimental group.

Gerbils were examined daily for clinical signs until the end of the experiment (60 days). The parameters that were evaluated were prostration, rough hair coats, anorexia, abdominal swelling, head tilt, incoordination, paralysis of limbs and circular movements (cerebral neosporosis), and other neurological signs (ataxia and pelvis limb weakness) (Aguado-Martínez et al., 2009). The evolution of the disease in different groups was classified according to Rojo-Montejo et al. (2011). Thus, it was determined that the acute phase of infection consisted of 1-5 days postchallenge and the chronic phase of infection of 14-30 days post-challenge.

The rodents were necropsied, and the tissues were evaluated macroscopically to assess any changes in volume, color and consistency. Tissues of each animal (encephalon, spinal cord, heart, lungs, liver, kidneys and spleen) were 
collected postmortem (as a consequence of the disease) or after euthanasia with inhaled isoflurane. In animals that were euthanized from day 18 post inoculation (p.i) the encephalon was sectioned into three fragments: posterior, including brain stem and cerebellum; central, including cerebral hemispheres and diencephalon; and frontal (Figure 1). All tissues were washed with phosphate saline (PBS) at the time of collection. The material was placed in microtubes and stored at $-20^{\circ} \mathrm{C}$ until processing.

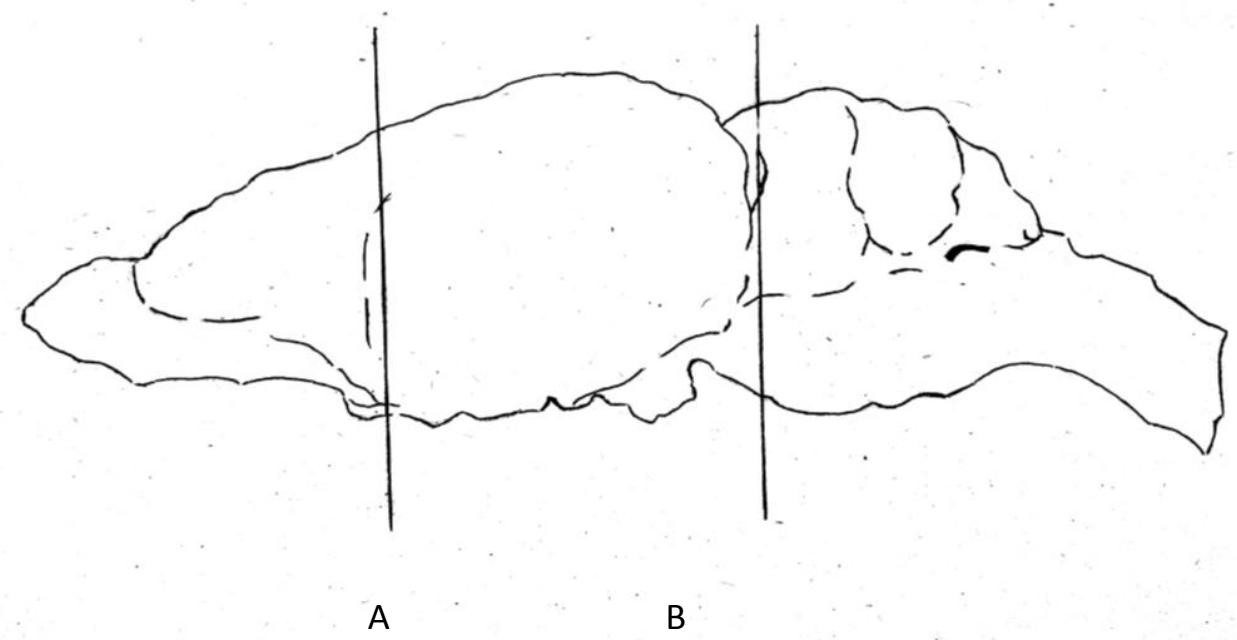

Figure 1. Representative localization of the encephalic regions sectioned from gerbils (Meriones unguiculatus) infected with Neospora caninum for DNA extraction and molecular analysis: A) Anterior; B) Central; C) Posterior sectioned in gerbils infected with Neospora caninum for DNA extraction and molecular analysis.

For DNA extraction, previous frozen samples were thawed and subsequently prepared using a commercial extraction kit (PureLink Genomic DNA kit, Invitrogen, USA), according to the manufacturer recommendations. The concentration and quality of DNA extracted from each sample were analyzed using spectrophotometer NanoDrop 1000 (absorbance of $260 / 280 \mathrm{~nm}$ ratio for purity evaluation) (Thermo Scientific, USA). After that, the DNA samples were stored at $-20^{\circ} \mathrm{C}$ until use.

PCR was performed using specific primers designed based on Nc-5 gene sequence of $N$. caninum (forward: TCCAATCCTGTAACGTGTTGCT, reverse: CACAAACAAAAAGGAGCCTTGCT)

resulting in a $328 \mathrm{bp}$ fragment as amplification product, as previously described (Yamage et al., 1996). PCR was performed in a total volume of $25 \mu \mathrm{L}$, containing 10X buffer (Promega, USA); $10 \mathrm{mM}$ dNTPs (Ludwig Biotec, Brazil); $50 \mu \mathrm{m}$ of each primer (Sigma-Aldrich, Brazil); 1U Taq DNA polymerase (Promega, USA); and 20-50ng of DNA as template. The amplification involved a denaturation phase at $95^{\circ} \mathrm{C}$ for $5 \mathrm{~min}$., followed by 40 cycles of $95^{\circ} \mathrm{C}, 1 \mathrm{~min}$; $60^{\circ} \mathrm{C}, 1 \mathrm{~min} ; 72^{\circ} \mathrm{C}$, $1 \mathrm{~min}$; and a final extension at $72^{\circ} \mathrm{C}$ by $5 \mathrm{~min}$ (T100 thermal cycler Bio-Rad, Singapore). The amplification products were analyzed by electrophoresis on $1 \%$ agarose gel and visualized by UV illumination. DNA of $N$. caninum tachyzoites was used as positive control for all reactions.

The encephalic tissues were submitted to qPCR analysis using standardized reagents (TaqMan Universal PCR Master Mix, Applied Biosystems, USA) with sets of primers and probes specific for the $\mathrm{Nc}-5$ gene of $N$. caninum (forward: TCCAATCCTGTAACGTGTTGCT, reverse: CACAAACAAAAAGGAGCCTTGCT and probe: FAM-CTGCGCCCAACAAC), as described by (Rojo-Montejo et al., 2011). For molecular analysis, $50 \mathrm{ng}$ of DNA from each sample was used in a $20 \mu \mathrm{L}$ reaction on 96-wells reaction plate. The reaction components used for each reaction were: $10 \mu \mathrm{L}$ of Master Mix $(2.0 \times)$, 
$2 \mu \mathrm{L}$ of IPC-Mix (10x); $0.4 \mu \mathrm{L}$ IPC DNA (50x); $1 \mu \mathrm{L}$ Primer/Probe Mix $(20 \times)$ and $4.6 \mu \mathrm{L}$ of Milli$\mathrm{Q}$ water. All the samples were analyzed in triplicate and the increase in fluorescence emission was detected using a FAM dye labeled TaqMan probe.

The amplification conditions were: $50^{\circ} \mathrm{C}$ for $2 \mathrm{~min}$., $95^{\circ} \mathrm{C}$ for $10 \mathrm{~min}$., and 40 cycles of $95^{\circ} \mathrm{C}$ for $15 \mathrm{sec}$. and $60^{\circ} \mathrm{C}$ for $1 \mathrm{~min}$. Fluorescence readings were made by the equipment 7500 real time PCR (Applied Biosystems, USA) at each amplification cycle and the data were analyzed by Sequence Detection Software v1.3 (Applied Biosystems,USA). An internal positive control (IPC) with optimized pre function of distinguishing true targets negative inhibitors of PCR reactions were used for the samples. We used the chi-square test with a significance level of $5 \%$ to assess between-group variation in the frequency of detection.

\section{RESULTS AND DISCUSSION}

In group $\mathrm{A}\left(\mathrm{n}=9 ; 5 \times 10^{4}\right.$ tachyzoites), five gerbils (numbered as \#1, \#2, \#3, \#4, \#5) showed clinical signs characteristic of acute neosporosis between days 7 to 11 . Three of these animals died on day 9 (\#1, \#2 and \#3), one died on day 10 (\#4), and one was euthanized on day 11 (\#5) due to very strong clinical signs. Other four gerbils (numbered as \#6, \#7, \#8, \#9) developed chronic disease and showed head tilt, incoordination, paralysis of limbs and circular movements, indicating cerebral neosporosis and were euthanized in extremis on days 58 (\#6) or day 60 (\#7, \#8 and \#9).

In group $\mathrm{B}\left(\mathrm{n}=8 ; 5 \times 10^{3}\right.$ tachyzoites), two gerbils (\#11 and \#12) died due to acute neosporosis on days 7 and 8, respectively. One gerbil (\#13) was euthanized on day 18 due to severe illness. Five gerbils (\#14, \#15, \#16, \#17, \#18) showed signs of chronic/persistent infection with neurological manifestations and were euthanized at day 60 p.i. However, these clinical signs appeared later when compared to Group A.

In group $\mathrm{C}\left(\mathrm{n}=10 ; 5 \times 10^{2}\right.$ tachyzoites $)$ no clinical signs of acute illness were evident. Therefore, three gerbils died between days 12 (one animal; \#21) to 13 (two animals; \#22 and \#23). Two animals died spontaneously on day 40 (\#24 and \#25). Signs of chronic infection were observed in five animals (\#26, \#27, \# 28, \#29 and \#30) that were euthanized at the end of the experiment (day 60 p.i.). However, clinical signs of neurological impairment were mild or absent.

In group $\mathrm{C}$, the infective dose in each animal was the lowest compared to the other two groups. We observed that this dose inoculated was probably insufficient to reproduce the infection in its fullness. In group $\mathrm{C}$, many of the clinical signs of infection were observed at the end of the experiment or near the time of death of animals. However, in animals 21, 22 and 23, the infection resulted in less severe clinical signs and death or euthanasia of animals.

Table 1 shows the distribution of $N$. caninum DNA in the spinal cord, heart, lungs, spleen, liver and kidneys of the gerbils in Groups A, B and C. A total of 11 gerbils died with clinical signs of acute neosporosis and $N$. caninum DNA was detected by PCR, as described in the Table 1 , from the following organs: lungs, spleen and kidneys (5/5), liver (2/5) and heart (1/5) in Group A; kidneys (3/3), lungs, spleen, liver (2/3) and heart (1/3) in Group B; kidneys (3/3), lungs, spleen $(2 / 3)$ and liver $(1 / 3)$ in the Group C. $N$. caninum DNA was not detected in central nervous system (spinal cord and encephalon) of the gerbils which died due to acute neosporosis (Tables 1 and 2). Besides that, $N$. caninum DNA was not detected in any organ in gerbils which died or were euthanized in the chronic phase of disease (Table 1).

DNA of $N$. caninum was not detected by PCR in any sample of the encephalon of gerbils. Based on an analysis of animals with evident neurological signs of chronic infection (i.e., animals 6 to 9) these samples were processed by another molecular technique, the qPCR which has been used in parasitology studies due his high sensibility and quantification capacity (Bell and Randford-Cartwright, 2002; Sebastiani et al., 2018). Therefore, encephalic tissues were submitted to a high sensitive qPCR with specific sets of primers and probes (TaqMan system) to increase the sensitivity of $N$. caninum DNA detection from tissue cysts in chronic infected animals and DNA of $N$. caninum was detected in sections of the encephalon of three animals: the anterior section of the encephalon of animal 6, the posterior section of the encephalon of animal 7 , and in each of the three sections of the 
encephalon of animal 8 (Table 2).In group B, DNA of $N$. caninum was detected by PCR in the tissues of animals 11, 12 and 13 (Table 1), representing the kidneys of $37.5 \%$ (3/8) of animals, the liver, spleen or lungs of $25 \%(2 / 8)$, and the heart of $12.5 \%$ (1/8). As in group A, DNA was not detected in the spinal cord of any animal.

Table 1. Detection of Neospora caninum DNA by PCR in tissue samples of gerbils (Meriones

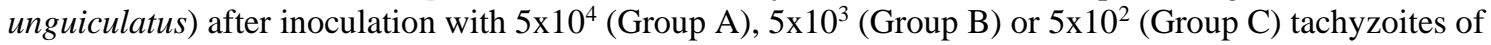
N. caninum

\begin{tabular}{|c|c|c|c|c|c|c|c|c|}
\hline \multirow{2}{*}{$\begin{array}{l}\text { Groups and } \\
\text { animal } \\
\text { numbers }\end{array}$} & \multirow[b]{2}{*}{ Days p.i. ${ }^{a}$} & \multicolumn{6}{|c|}{ Tissues analyzed } & \multirow[b]{2}{*}{ Total } \\
\hline & & $\begin{array}{l}\text { Spinal } \\
\text { cord }\end{array}$ & Heart & Lungs & Spleen & Liver & Kidneys & \\
\hline A\#1 & $9 *$ & - & - & + & + & + & + & $4 / 6$ \\
\hline $\mathrm{A \# 2}$ & $9 *$ & - & - & + & + & - & + & $3 / 6$ \\
\hline A\#3 & $9 *$ & - & - & + & + & + & + & $4 / 6$ \\
\hline A\#4 & $10 *$ & - & - & + & + & - & + & $3 / 6$ \\
\hline A\#5 & $11 *$ & - & + & + & + & - & + & $4 / 6$ \\
\hline A\#6 & 58 & - & - & - & - & - & - & $0 / 6$ \\
\hline A\#7 & 60 & - & - & - & - & - & - & $0 / 6$ \\
\hline A\#8 & 60 & - & - & - & - & - & - & $0 / 6$ \\
\hline A\#9 & 60 & - & - & - & - & - & - & $0 / 6$ \\
\hline Total & & $0 / 9$ & $1 / 9$ & $5 / 9$ & $5 / 9$ & $2 / 9$ & $5 / 9$ & \\
\hline $\mathrm{B} \# 11$ & $7 *$ & - & - & + & + & + & + & $4 / 6$ \\
\hline B\#12 & $8 *$ & - & - & - & + & + & + & $3 / 6$ \\
\hline B\#13 & $18 *$ & - & + & + & - & - & + & $3 / 6$ \\
\hline B\#14 & 60 & - & - & - & - & - & - & $0 / 6$ \\
\hline B\#15 & 60 & - & - & - & - & - & - & $0 / 6$ \\
\hline B\#16 & 60 & - & - & - & - & - & - & $0 / 6$ \\
\hline B\#17 & 60 & - & - & - & - & - & - & $0 / 6$ \\
\hline B\#18 & 60 & - & - & - & - & - & - & $0 / 6$ \\
\hline Total & & $0 / 8$ & $1 / 8$ & $2 / 8$ & $2 / 8$ & $2 / 8$ & $3 / 8$ & \\
\hline $\mathrm{C \# 21}$ & $12 *$ & - & - & + & + & + & + & $4 / 6$ \\
\hline $\mathrm{C \# 22}$ & $13 *$ & - & - & + & - & - & + & $2 / 6$ \\
\hline $\mathrm{C \# 23}$ & $13 *$ & - & - & - & + & - & + & $2 / 6$ \\
\hline $\mathrm{C \# 24}$ & 40 & - & - & - & - & - & - & $0 / 6$ \\
\hline $\mathrm{C \# 25}$ & 40 & - & - & - & - & - & - & $0 / 6$ \\
\hline C\#26 & 60 & - & - & - & - & - & - & $0 / 6$ \\
\hline $\mathrm{C \# 27}$ & 60 & - & - & - & - & - & - & $0 / 6$ \\
\hline C\#28 & 60 & - & - & - & - & - & - & $0 / 6$ \\
\hline C\#29 & 60 & - & - & - & - & - & - & $0 / 6$ \\
\hline $\mathrm{C \# 30}$ & 60 & - & - & - & - & - & - & $0 / 6$ \\
\hline Total & & $0 / 10$ & $0 / 10$ & $2 / 10$ & $2 / 10$ & $1 / 10$ & $3 / 10$ & \\
\hline
\end{tabular}

Based on the qPCR (Table 2), N. caninum DNA was detected in the encephalon of five out of six animals in group B. In animals 13 and 15, N. caninum DNA was detected in each of the three sections of the encephalon. In animal $17, \mathrm{~N}$. caninum DNA was detected only in the anterior section of the encephalon. In animals 18 and 19, $N$. caninum DNA was detected only in the central region of the encephalon. 
Table 2. Detection of Neospora caninum DNA by real time PCR in encephalon sections from chronic infected gerbils (Meriones unguiculatus) inoculated with $5 \times 10^{4}$ (Group A), $5 \times 10^{3}$ (Group B) or $5 \times 10^{2}$ (Group C) tachyzoites of N. caninum

\begin{tabular}{|c|c|c|c|c|c|c|c|c|c|c|c|c|c|c|c|c|}
\hline \multirow{4}{*}{$\begin{array}{l}\text { Encephali } \\
\text { c } \\
\text { sections* }\end{array}$} & \multicolumn{16}{|c|}{ Groups $(\mathrm{A}, \mathrm{B}, \mathrm{C})$ and identification numbers of the chronic infected gerbils } \\
\hline & A & A & A & A & $\mathrm{B}$ & B & B & B & B & B & $\mathrm{C}$ & $\mathrm{C}$ & $\mathrm{C}$ & $\mathrm{C}$ & $\mathrm{C}$ & \multirow{3}{*}{$\begin{array}{l}\text { Tota } \\
1\end{array}$} \\
\hline & \# & \# & \# & \# & \#1 & \#1 & \#1 & \#1 & \#1 & \#1 & \#2 & \#2 & \#2 & $\# 2$ & \#3 & \\
\hline & 6 & 7 & 8 & 9 & 3 & 4 & 5 & 6 & 7 & 8 & 6 & 7 & 8 & 9 & 0 & \\
\hline Anterior & + & - & + & - & + & - & + & + & + & + & - & - & - & - & - & $7 / 15$ \\
\hline Central & - & - & + & - & + & - & + & - & + & + & - & - & - & - & - & $5 / 15$ \\
\hline Posterior & - & + & + & - & + & - & + & - & - & - & - & - & - & - & + & $5 / 15$ \\
\hline
\end{tabular}

*The sections are described at Figure 1.

In group $\mathrm{C}, N$. caninum DNA was detected by PCR in only four animals (Table 1). The frequency of detection was greatest in the kidneys (3/10), followed by lungs and spleen $(2 / 10)$ and liver (1/10). All positive samples were collected from just three animals in group $\mathrm{C}$ (\#21, \#22 and \#23). DNA of $N$. caninum was not found in the spinal cord or heart of animals in group $\mathrm{C}$. In the analysis of sections of encephalon tissue by qPCR, only animal number 30 was positive in the posterior region.

Based on previous studies with other animal models (Eperon et al., 1999; Lidell et al., 1999; Collantes-Fernández et al., 2002; DittrichLocatelli et al., 2018), it is known that the CNS, especially the brain, is considered one of the preferred sites for establishment of cysts during the chronic infection phase of $N$. caninum. However, the CNS segmentation aimed at determining which area of the encephalon is a preferred site for the establishment of cysts of $N$. caninum was not performed. In the present study, we assessed the presence of $N$. caninum DNA in different sections of the CNS. In animals with clinical signs of chronic infection, $N$. caninum DNA was detected in the anterior sections of the encephalon in 7 of $10(70 \%)$ gerbils in groups A and B. Furthermore, it is important to observe that in group $\mathrm{C}, N$. caninum DNA was detected in only one animal (i.e., in the posterior section of the encephalon of animal \#30). Based on this data, it is possible that the inoculated dose in group $\mathrm{C}$ was insufficient to assess infection and the expression of any neurological evidence of cerebral neosporosis in these animals.

Thus, the course of the disease was determined by the amount of inoculum that was used to cause the disease. Our study shows that the dose of $N$. caninum inoculated was determinant for the presence, type and frequency of clinical signs of acute disease in gerbils. In groups $\mathrm{A}$ and $\mathrm{B}$, we found that the protozoan replicated efficiently in most animals and the dosages of tachyzoites used facilitated the successful establishment of infection. In animals that survived the acute infection, the process evolved into a chronic/persistent infection without inducing severe and lethal clinical signs (Gottstein et al., 2001; Collantes-Fernández et al., 2002).

Comparing the results obtained in this experiment with previous studies (Toscan et al., 2012), we observed that the dose that was used to inoculate animals in our study significantly interfered with the induction of acute and chronic infection. This suggests that the ability of each rodent to control the multiplication of the parasites depends on the initial dose of infection. In addition, this effect of the dose is reflected in the amount of detection of parasite nucleic acids in different tissues, particularly in the CNS (Long et al., 1998; Gottstein et al., 2001).

In this context, we observed that spontaneous death of some animals in group $\mathrm{C}$, occurred later than in other groups and near day 15 p.i., which is considered by Gottstein et al. (2001) a critical point for selection between significant distribution of parasite and immune defense (reduction in the amount and distribution of tachyzoites). In addition, studies with models of chronic infection with $N$. caninum can be used to evaluate pathogenesis, modulation of the disease course, and persistence in the CNS and to study the factors that influence recrudescence which would be difficult to achieve using cattle (Innes et al., 2000; Collantes-Fernández et al., 2002).

To provide satisfactory data regarding acute or chronic neosporosis it is important that each animal model has been tested using an exact dose of tachyzoites for the challenge and resulting in 
clear parameters for clinical signs evaluation. These aspects are fundamental to develop control methods and diagnostic tests for $N$. caninum.

Therefore, the present study shows that the dose of $5 \times 10^{3}$ tachyzoites of $N$. caninum $(\mathrm{Nc}-1$ strain) $/ \mathrm{mL}$ was the most effective to induce chronic infection in female gerbils $(M$. unguiculatus), because it resulted in higher morbidity if compared to the dose of $5 \times 10^{2}$ and reduced mortality by acute neosporosis in comparison to the dose of $5 \times 10^{4}$. In addition, acute neosporosis was strongly related with detection of $N$. caninum DNA by PCR in organs as lungs, spleen, kidneys, liver and heart whilst $N$. caninum DNA detection by qPCR in encephalon, preferentially in anterior region, was strongly related to the chronic phase of neosporosis.

Furthermore, it is important to ensure the appropriate use of the gerbil as an animal model in order to support studies related to (a) cytokine profiles in both stages of the disease, (b) drug treatment and vaccine development, (c) antibody responses and (d) percentage of transmission.

\section{CONCLUSION}

Acute or chronic neosporosis outcome in gerbils as an experimental model is determined by the inoculum dose and genomic detection of $N$. caninum which occurs in the gerbil's systemic organs during acute phase and in encephalon when chronic neosporosis is established.

\section{REFERENCES}

AGUADO-MARTÍNEZ A.; ORTEGA-MORA L.M.; ÁLVAREZ-GARCÍA G. et al. Stagespecific expression of NcSAG4 as a marker of chronic Neospora caninum infection in a mouse model. Parasitology, v.136, p.757-764, 2009.

BELL A.S.; RANDFORD-CARTWRIGHT L. Real-time quantitative PCR in parasitology. Trends Parasitol., v.18, p.337-342, 2002.

COLLANTES-FERNÁNDEZ E.; ZABALLOS A.; ÁLVAREZ-GARCÍA G. et al. Quantitative detection of Neospora caninum in bovine aborted fetuses and experimentally infected mice by realtime PCR. J. Clin. Microbiol., v.4, p.1194-1198, 2002.
COSTA R.C.; MESQUITA L.P.; NUNES M.V.L. et al. Neospora caninum bioassay in gerbils using placental tissues from naturally infected goats. Vet. Parasitol., v.249, p.70-73, 2018.

DITTRICH-LOCATELLI R.; REGIDORCERRILLO J.; ORTEGA-MORA L.M. et al. Isolation of Neospora caninum from kidney and brain of a bovine fetus and molecular characterization in Brazil. Exp. Parasitol., v.185, p.10-16, 2018.

DUBEY J.P.; LINDSAY D.S. A review of Neospora caninum and neosporosis. Vet. Parasitol., v.67, p.1-59, 1996.

DUBEY J.P.; SCHARES G. Neosporosis in animals, the past five years. Vet. Parasitol., v.180, p.90-108, 2011.

ELLIS J.; MILlER C.; QUINN H. et al. Evaluation of recombinant proteins of Neospora caninum as vaccine candidates (in a mouse model). Vaccine, v.47, p.5989-5996, 2008.

EPERON S.; BRÖNNIMANN K.; HEMPHILL A. et al. Susceptibility of B-cell deficient C57BL/6 (microMT) mice to Neospora caninum infection. Parasitol Immunol., v.21, p.225-236, 1999.

GONDIM L.F.P.; PINHEIRO A.M.; SANTOS P.O.M. et al. Isolation of Neospora caninum from the brain of a naturally infected dog, and production of encysted bradyzoites in gerbils. Vet. Parasitol., v.101, p.1-7, 2001.

GOTTSTEIN B.; EPERON S.; DAI W.J. et al. Efficacy of toltrazuril and ponazuril against experimental Neospora caninum infection in mice. Parasitol. Res., v.87, p.43-48, 2001.

INNES E.A.; BUXTON D.; MALEY S. et al. Neosporosis: aspects of epidemiology and host immune response. Ann. N. Y. Acad. Sci., v.916, p.93-101, 2000.

LIDDELL S.; JENKINS M.C.; DUBEY J.P. Vertical transmission of Neospora caninum in $\mathrm{BALB} / \mathrm{c}$ mice determined by polymerase chain reaction detection. J. Parasitol., v.85, p.550-555, 1999.

LONG M.T.; BASZLER T.V.; MATHISON B.A. Comparison of intracerebral parasite load, lesion development and systemic cytokines in mouse strains infected with Neospora caninum. J. Parasitol., v.84, p.316-320, 1998. 
RAMAMOORTHY S.; SRIRANGANATHAN N.; LINDSAY D.S. et al. Gerbil model of acute neosporosis. Vet. Parasitol., v.127, p.111-114, 2005.

ROJO-MONTEJO S.; COLLANTESFERNÁNDEZ E.; REGIDOR-CERRILLO J. et al. Influence of adjuvant and antigen dose on protection induced by an inactivated whole vaccine against Neospora caninum infection in mice. Vet. Parasitol., v.175, p.220-227, 2011.

SEBASTIANI C.; CURCIO L.; CIULLO M. et al. A multi-screening Fast qPCR approach to the identification of abortive agent in ruminants. $J$. Microbiol. Methods, v.148, p.12-17, 2018.

TOSCAN G.; CAMILLO G.;; WEBER A. et al. Detecção de ácidos nucléicos em tecidos de gerbils submetidos à infecção aguda por Neospora caninum. Ciênc. Rural, v.42, p.18651871, 2012.

YAMAGE M.; FLECHTNER O.; GOTTSTEIN B. Neospora caninum: specific oligonucleotide primers for the detection of brain "cyst" DNA of experimentally infected nude mice by the polymerase chain reaction. J. Parasitol., v.82, p.272-279, 1996. 